\title{
The Analysis of the Age Structure of Regional Fixed Capital in the Agriculture
}

\author{
P. Mazouch ${ }^{1}$, I. Krejčíi ${ }^{2}$
}

${ }^{1}$ Department of Economic Statistics, Faculty of Informatics and Statistics, University of Economics, Prague

${ }^{2}$ Department of Systems Engineering, Faculty of Economics and Management, Czech University of Life Sciences Prague

\begin{abstract}
The paper deals with an estimate and analysis of the value of regional net fixed capital stock and the age structure of machinery and equipment in Czech agriculture. In order to perform such analysis, the official model of perpetual inventory method is transformed into the Markov chain model and applied on regional data separately. Regional net fixed capital stock is presented for the period of 2008-2013.

The development of the average age of machinery and equipment comprises a potential indicator of the modernisation process in the industry. The analysis of the age structure is based on the structure heterogeneity indicator. For these purposes, the real age structure in each Czech region is compared with the theoretical stable and stationary structure. Currently, the most heterogeneous age structure of machinery and equipment occurs in Prague and the Karlovy Vary region.
\end{abstract}

\section{Keywords}

Average age of assets, Markov chain, fixed capital stock, perpetual inventory method, regional capital stock.

Mazouch, P. and Krejčí, I. (2016) "The Analysis of the Age Structure of Regional Fixed Capital in the Agriculture ", AGRIS on-line Papers in Economics and Informatics, Vol. 8, No. 2, pp. 89-101. ISSN 1804-1930, DOI: 10.7160/aol.2016.080207.

\section{Introduction}

Capital represents one of the most important factors of production in a national economy. However, expressing the value of capital goods relates to several issues which substantially affect the research activities and results. Moreover, even if the official estimate of the capital value is available, the official statistics may lack the necessary detail.

The first problem occurs with the most obvious form of capital - the book value. This indicator suits business practice sufficiently but does not work in an analysis of economic principles (Pigou, 1935). The book value represents an aggregate of historical prices (i.e. it sums prices from various periods without any revaluation) and depreciation arises mainly from current legislation and the owner's decision, whereas an asset with a zero book value could still prove productive and sellable, i.e. has a non-zero market value (Diewert, 2005; Hulten and Wykoff, 1996).

This problem of business bookkeeping data is accepted on the international level. Therefore, capital stock is measured by means of Perpetual Inventory Method (PIM) (OECD, 2009; United Nations et al., 2009). Although the Cambridge capital controversy (Robinson, 1953; Harrod and Sraffa, 1961) did not arrive at a completely clear solution and some authors consider the death of the main protagonists as the reason why the debate calmed down (Cohen and Harcourt, 2003), the international standards for measuring fixed capital are based mainly on the neoclassical capital theory (OECD, 2009).

Nowadays, fixed capital constitutes an integral part of national accounts statistics of developed countries in the form of various kinds of stock and flows computed via model computation. To solve the bookkeeping issues, the PIM model aggregates the flow of investment (gross fixed capital formation), which allows a survey on a regular basis. On the other hand, the outflows of depreciation and retirement must be modelled based on the real service life of assets. All assets are revaluated to basic year prices before their integration 
into stock. (OECD, 2009)

Various studies employed capital indicators of Czech agriculture as an input variable. Despite the weaknesses of the book value, some authors (Kočišová, 2015; Nowak et al., 2015) prefer data from the Farm Accountancy Data Network (FADN) for all model variables, even for whole countries where the data on fixed capital exist in a required form. On one hand, using a single data source always represents an advantage. On the other hand, however, the used FADN database draws its numbers from bookkeeping data (European Commision, 2005). The FADN provides the data on fixed capital in replacement costs (European Commision, 2010). The replacement value is obtained from the index revaluation according to the estimation of the average age of fixed capital stock, which is estimated on the basis of the ratio of the accumulated bookkeeping depreciation (Barkaszi et al., 2009, European Commision, 2015). Therefore, the FADN takes inflation into account. The FADN revaluation shows an increase of depreciation by approximately one third in comparison with the acquisition costs (European commission, 2016). Nevertheless, the bookkeeping service life is used and neither the time series of investment nor the variability in age structure are reflected.

Due to the missing data on capital stocks in regional (Czech Statistical Office, 2015a) various alternative solutions have occurred. Bielik and Hupková (2011) uses the total assets from survey (book value) as an input for technical efficiency analysis. Špička and Smutka (2014) uses FADN capital indicators for milk farms regional technical efficiency. Latruffe and Piet (2014) use FADN data on capital for farm performance on NUTS3 level of Brittany. Čechura (2010, 2012) use data form CreditInfo Firms Monitor, i.e. the book value of capital. Špička (2014) uses book value of capital from FADN for technical efficiency analysis of mixed farming on the level of EU regions.

The fixed capital or selected characteristics of fixed capital are implicitly part of many other studies focused on modernization or ICT development in the Czech agriculture (Jarolímek et al., 2014; Vaněk et al., 2010). Moreover, the modernization and support of investment into new technologies is also the aim of strategies, plans and programmes (Hlaváček et al., 2012; Ministry of Agriculture of the Czech Republic, 2008). Since the modernization is defined as the strategic goal, it should be connected with the measurable indicator
(Doran, 1981; Lawler and Bilson, 2013). Otherwise, managers would not be able to evaluate whether the goal has been reached or not. Moreover, it would be impossible to evaluate the necessity of such goal either.

From that point of view the age of fixed capital represents a possible indicator. Thus, a decrease or at least stability of the average age characterizes the modernization process. However, the age of fixed capital does not represent a common part of official statistics (Harper, 2008). As the national accounts statistics (the Czech Statistical Office, 2015b) publish mainly indicators that express the value of flows and stock, Krejčí et al. (2015) estimate the age of fixed capital in agriculture and compare it with available international data on the age of capital. This research shows that the average age of fixed capital in the Czech Republic reaches a similar level as in the USA and Australia. However, the presented results deal with the age structure for the whole Czech Republic. A significant part of the referred analyses concerns regional data. For a wider applicability of the estimated indicators, improving the relevance and providing the regional detail comprise a necessary step.

The paper aims firstly at estimating and analysing the age of machinery and equipment in Czech agriculture in a regional breakdown. The analysis includes the statement of equilibrium investment and a comparison of a stable and a real age structure for Czech regions (Czech "kraj", NUTS III). Subsequently, due to necessary adjustments of the model, we estimate the value of regional net fixed capital stock in Czech agriculture. In order to do so, we use the adjusted model of PIM and perform multiple computations to obtain the stock and age structure of the machinery and equipment.

\section{Materials and methods}

Albala-Bertrand and Feng (2007) suggest the estimation of regional capital stock via the production function and linear programing. However, using production as an input variable for the capital estimation would lead to difficulties in the future application to the productivity and efficiency analysis. Therefore, we apply a similar approach as Derbyshire, Gardiner, and Waights (2013). Nevertheless, those authors used the same service lives and retirement functions for all countries.

The regional stock in our research is computed similarly to national stock via PIM with gross fixed 
capital formation as the main model input (OECD, 2009) but divided into regions. For these purposes we apply the Czech official service lives and retirement functions (40 years for non-residential buildings in agriculture, 15.9 years for transport equipment, 14.7 years for other machinery and equipment, etc. see the Czech Statistical Office (2002)).

For the estimation of the regional capital stock in agriculture, we apply the straight-line depreciation, which corresponds with the official approach (the Czech Statistical Office, 2002). The $p_{k}$ represents the value of the asset in the age equal to $\mathrm{k}$ and $p_{0}$ is the value of a new asset while $m$ expresses the maximum service life:

$$
\frac{p_{k}}{p_{0}}=1-\frac{k}{m}, \quad k=0,1, \ldots, m .
$$

As the age of fixed capital in this paper is estimated as a modernization indicator, we calculate the age only for machinery and equipment. Considering the most significant types of assets, machinery and equipment, non-residential buildings and cultivated biological resources represented $97.87 \%$ of gross fixed capital stock in Czech agriculture in 2013 (the Czech Statistical Office, $2015 \mathrm{~b}$ ). The age of cultivated assets does not directly relate to modernization and aging of buildings does not necessarily represent obsolescence (for the age of the whole fixed capital stock in Czech agriculture see (Krejčí et al., 2015)).

Regional statistics on gross fixed capital formation in the industry and NUTS 3 disaggregation (Czech Statistical Office, 2015a) contain only data from the period between 1995 and 2012. The year 2013 presents only numbers without the industry structure. For the purposes of stock estimation, we also need to divide older data on gross fixed capital formation which represent the input for the PIM. We apply the average ratio of regional gross fixed capital formation. Nevertheless, only $5.43 \%$ of the machinery and equipment gross capital stock in 2013 consists of capital from the period before 1995.

The average age of the fixed capital is the weighted average of the age of past investment (gross fixed capital formation), where the weight consists of the current value of the part of past investment (U.S. Bureau of Economic Analysis, 2013). In order to obtain the age structure, we apply the transformation of PIM into the Markov chain (Krejčí and Sixta, 2012; Krejčí, 2010). Since the stages in the aging process (i.e. retirement or age cohort) depend only on the previous state and transition probabilities and the process proves memoryless, the aging process has the Markov property (Tijms, 2003), where $n$ is the stage and $X$ represents the state of the process:

$$
\begin{aligned}
P\left(X_{n}\right. & \left.=i_{n} \mid X_{0}=i_{0}, \ldots, X_{n-1}=i_{n-1}\right)=P\left(X_{n}=i_{n} \mid X_{n-1}\right. \\
& \left.=i_{n-1}\right) .
\end{aligned}
$$

We establish the estimation on the analogy with demography. Therefore, we consider the gross fixed capital stock as the most suitable for age estimation. As the productivity of population does not affect the age of population, we disregard the influence of the wear and tear of the machinery and equipment.

The transition matrix $\boldsymbol{P}$ arises from the official mostly log-normal retirement function (Czech Statistical Office, 2002). The matrix contains $m+1$ columns and rows, where $m$ has the same meaning as in $(1)$ and $(m+1)^{\text {th }}$ represents the absorbing state of retired assets from the examined period. Columns and rows from 1 to $m$ represent age cohorts.

National accounts and thus also the PIM does not express capital stock as a number of various assets but as the value of assets, which provides comparability and homogeneity of asset expression. Therefore, the calculation of the transition matrix elements follows a similar way as the maintenance models (Tijms, 2003; van der Duyn Schouten and Vanneste, 1990). The probability of asset retirement in the $i^{\text {th }}$ year of service $-a_{i}$ - arises from the official retirement function used for national accounts estimations (the Czech Statistical Office, 2015b). The survival probability of the $\mathrm{i}^{\text {th }}$ year $r_{i}$ subsequently emerges from (3). Individual elements of $\boldsymbol{P}$ are calculated from the (4) and (5). The conditional probability that the asset will retire in the $\mathrm{i}^{\text {th }}$ year is $p_{i, m+1}$ and $p_{i, i+1}$ represents the conditional probability of aging from $i$ to $i+1$.

$$
\begin{aligned}
& r_{i-1}-r_{i}=a_{i}, i=0, \ldots, m, r_{0}=1, \\
& p_{i, m+1}=\frac{a_{i}}{r_{i-1}}, i=1, \ldots, m, \\
& p_{i, i+1}=\frac{r_{i}}{r_{i-1}}, i=1, \ldots, m-1 .
\end{aligned}
$$

Table 1 shows the example of the transition matrix $\boldsymbol{P}$ for transport equipment in Czech agriculture. The absorbing state has a value of 1 on the main diagonal (the process cannot leave the absorbing state). In our case the absorbing state corresponds to the "retired" state.

Consequently, the vector of gross capital stock $\boldsymbol{g}_{t}$ in the year $t$ arises from:

$g_{t}^{T}=g_{t-1}^{T} P$. 


\begin{tabular}{|c|c|c|c|c|c|c|c|c|c|c|c|c|}
\hline & 1 & 2 & 3 & 4 & 5 & 6 & $\ldots$ & 35 & 36 & 37 & 38 & retired \\
\hline 1 & 0 & 1.0000 & 0 & 0 & 0 & $\mathbf{0}$ & 0 & 0 & 0 & 0 & 0 & 0.0000 \\
\hline 2 & 0 & 0 & 1.0000 & 0 & 0 & 0 & 0 & 0 & 0 & 0 & 0 & 0.0000 \\
\hline 3 & $\mathbf{0}$ & 0 & 0 & 1.0000 & 0 & 0 & $\mathbf{0}$ & 0 & 0 & 0 & 0 & 0.0000 \\
\hline 4 & $\mathbf{0}$ & 0 & 0 & $\mathbf{0}$ & 0.9999 & 0 & $\mathbf{0}$ & $\mathbf{0}$ & 0 & 0 & 0 & 0.0001 \\
\hline 5 & $\mathbf{0}$ & 0 & 0 & 0 & 0 & 0.9989 & $\mathbf{0}$ & $\mathbf{0}$ & 0 & 0 & 0 & 0.0011 \\
\hline$\cdots$ & $\cdots$ & & & & & & $\cdots$ & & & & & \\
\hline 35 & 0 & 0 & 0 & 0 & o & 0 & $\mathbf{0}$ & $\mathbf{0}$ & 0.8091 & 0 & 0 & 0.1909 \\
\hline 36 & 0 & 0 & 0 & 0 & 0 & 0 & $\mathbf{0}$ & 0 & 0 & 0.8094 & 0 & 0.1906 \\
\hline 37 & 0 & 0 & 0 & 0 & 0 & 0 & 0 & $\mathbf{0}$ & 0 & 0 & 0.8099 & 0.1901 \\
\hline 38 & 0 & 0 & 0 & 0 & 0 & 0 & $\mathbf{0}$ & $\mathbf{0}$ & 0 & 0 & 0 & 1.0000 \\
\hline retired & 0 & 0 & 0 & 0 & 0 & 0 & $\mathbf{0}$ & $\mathbf{0}$ & 0 & 0 & 0 & 1.0000 \\
\hline
\end{tabular}

Source: own processing

Table 1: Example of transition matrix $\mathrm{P}$ for transport equipment.

The sum of first $m$ elements of gt equals the total value of gross fixed capital while last $(m+1)^{\text {th }}$ element represents the aggregation of retired capital from the examined period. A full description of the implemented software with an alternative Czech PIM calculation appeared in Krejčí and Sixta (2012).

The age structure of fixed capital differs not only by type of capital but also by region. For the description of the structure, many characteristics may be used. Most applicable are the average age of capital, the median of the capital age or any other quantiles (Krejčí et al., 2015). Fluctuation of those characteristics in time depends on a short-term excess or a deficiency of new investment. Such a fluctuation is not desired from the point of view of stability of the structure of capital. Waves caused by a higher or lower intensity of new investment are reflected in the age structure for a long time (up to 40 years when all of the investment are retired). Although an excess wave proves positive at younger ages (a higher share of young capital), in higher ages this wave presents a burden. The value of aged and obsolete capital is going to grow because of such a wave. Moreover, the retired capital grows and demands a new wave of investment for consequent renewal. Therefore, a past short term solution can simply become a current problem.

Similarly to demography, one of the goals should be stable age structure of capital in time. If the amount of new input into the first cohort keeps stable (no matter if the amount remains constant, or constantly increasing or decreasing - the coefficient of annual change stays constant in time) and the principle of exclusion from population stays constant (retirement in the case of capital), then the amount of capital increases constantly (or decreases mirroring the increase or decrease of the input) and the age structure remains stable in time (Lotka, 1939).

A situation where the amount of new investment stays constant in time represents a special case of a stable structure. The process follows the Little's Law (Little, 1961). After a certain period of time, based on the delay between the input and output of population stock, the input becomes equal to output (investment is equal to retired capital in our case). This special case is called the "Stationary" structure (Lotka, 1939).

For a basic analysis, we test the relation between the population parameters and the investment behavior impact. Table 2 shows the result of a hypothetical constant annual growth of new investment and the average age of machinery and equipment in Czech agriculture. The stationary structure of Transport equipment has an average age of 9.04 years while Other machinery and equipment 8.35 years. If the aim was to reach a lower average age than for the Stationary structure, it would require an application of an annual growth of the amount of new investment in Table 2.

Figure 1 illustrates the proportions of stable populations with different coefficients of growth of new investment. The stable structure (no matter for which coefficient of investment growth, if bellow or over 1) shows that proportions (as ratio of the whole amount of capital) of age groups remain constant in time. For a situation where the coefficient is below 1, the population has a lower proportion of younger capital and the total amount of capital clearly decreases. Demography denominates such structure as a Regressive 


\begin{tabular}{|c|c|c|}
\hline \multirow{2}{*}{$\begin{array}{c}\text { Annual growth } \\
\text { of investment }\end{array}$} & \multicolumn{2}{|c|}{ Average age of capital } \\
\cline { 2 - 3 } & Transport Equipment & $\begin{array}{c}\text { Other Machinery } \\
\text { and Equipment }\end{array}$ \\
\hline$-10 \%$ & 15.0 & 13.3 \\
\hline$-5 \%$ & 11.5 & 10.4 \\
\hline$-3 \%$ & 10.4 & 9.5 \\
\hline$-2 \%$ & 9.9 & 9.1 \\
\hline$-1 \%$ & 9.5 & 8.7 \\
\hline $0 \%$ & 9.0 & 8.4 \\
\hline $1 \%$ & 8.6 & 8.0 \\
\hline $2 \%$ & 8.3 & 7.7 \\
\hline $3 \%$ & 7.9 & 7.4 \\
\hline $5 \%$ & 7.3 & 6.9 \\
\hline $10 \%$ & 6.0 & 5.7 \\
\hline $15 \%$ & 5.1 & 4.9 \\
\hline
\end{tabular}

Source: own processing

Table 2: Annual growth of new investment and correspondent average age of capital for Transport Equipment and Other Machinery and Equipment

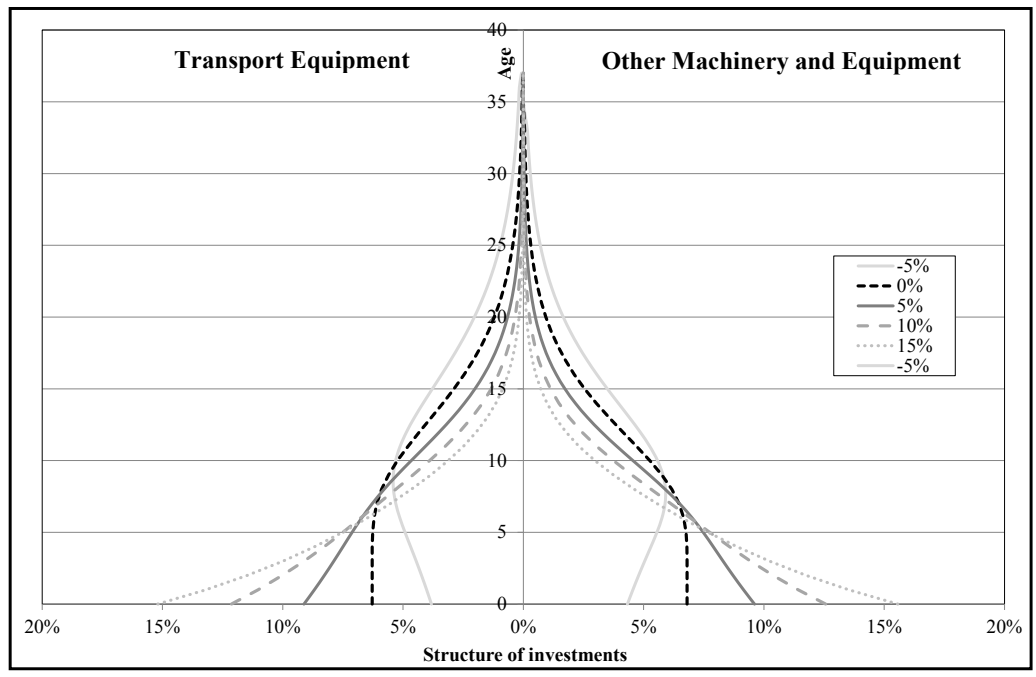

Source: own processing

Figure 1: Impact of various levels of annual growth of new investment on age structure of Transport equipment and Other machinery and equipment.

population which is typical for developed countries (Roubíček, 1997). If the coefficient equals 1 (the amount of new investment equals retired capital and the total amount of capital stays constant), the structure is stationary (a curve for $0 \%$ ). If the coefficient exceeds 1, the structure is progressive and the proportions of younger age groups are larger with the total amount of capital increasing. A progressive population is typical for developing countries with a birth rate higher than mortality rates (Roubíček, 1997).

To evaluate the difference between a real and stable age structure of capital we adopt a simple indicator. This indicator quantifies the difference between the real and both the stable and stationary age structure.

For the quantification of the difference $\boldsymbol{D}_{\boldsymbol{u}, \boldsymbol{c}}^{\boldsymbol{s}}$ between the real and stationary structure for the region $u$ and the type of capital $c$, the formula is:

$\boldsymbol{D}_{u, c}^{s}=\sum_{i=0}^{m}\left(s_{i, u, c}^{r}-s_{i, c}^{s}\right)^{2}$,

where $s_{i, \boldsymbol{u}, \boldsymbol{c}}^{r}$ represents the real share of capital of the age $i$ on the total value of capital. The type of capital in this case is Transport equipment 
or Other machinery and equipment. The variable $\boldsymbol{s}_{\boldsymbol{i}, \boldsymbol{c}}^{\boldsymbol{s}}$ states the same for a stationary population. The $u$ is missing in the subscript because the model parameters (average service life and a retirement function) remain the same for various regions. The quantification of the difference between the real and stable structure $b$ (with a constant coefficient of growth of new investment in time) we use a similar equation:

$\boldsymbol{D}_{u, \boldsymbol{c}}^{\boldsymbol{b}}=\sum_{i=0}^{m}\left(s_{i, u, c}^{r}-s_{i, c}^{b}\right)^{2}$,

\section{Results and discussion}

Table 3 shows the value of net fixed capital stock in NACE A - Agriculture, Forestry and Fishing (the Czech Statistical Office, 2015c) in individual years for the given period. The sum of value of all regional stocks equals the annual national accounts value (the Czech Statistical Office, 2015b) in constant prices of 2010 .

Despite the necessary methodology adjustments, Krejčí et al (2015) compared the average age of capital on international basis. That research compared the age in the Czech Republic with capital age in the USA and Australia for the period 2000-2012. This international comparison showed smaller differences (e.g. net capital stock computed by geometric depreciation profile showed average age in Czech Republic 6.9 and 6.6 in USA) in the comparison with the current research focused on the Czech regions.

Figure 2 shows the development of the average age of machinery in Czech NUTS 3 regions. Similarly to Krejčí et al. (2015) the graph contains a simple extrapolation of age development which keeps the investment at the current level (the average ratio of regional investment for 2013 and 5-year moving average of gross fixed capital formation from the year 2014 to 2020). The average age of machinery in the whole Czech Republic in the period of 2000-2013 was 8.29 years and it decreased by 1.06 years during that period. The average difference between the lowest and highest regional age of machinery and equipment reached 3.27 years. However, in the case of stable investment the difference would decrease to 1.60 years in 2020 .

Prague shows the lowest average age, however the impact of the region on the overall average age of machinery stays very little. Despite the share of Prague having increased more than four times since 2000, the share of Prague on total gross capital stock of machinery and equipment in agriculture reached only $1.71 \%$ in 2013. Consequently, the average age of machinery with and without Prague exhibit only marginal differences.

Omitting Prague, the lowest average age of machinery and equipment in the period of 2000-2013 occurs in the Karlovy Vary region.

\begin{tabular}{|c|c|c|c|c|c|c|}
\hline Region & \multicolumn{6}{|c|}{ Net fixed capital stock, constant prices prices 2010, mil. CZK } \\
\hline NACE & 2008 & 2009 & 2010 & 2011 & 2012 & 2013 \\
\hline The Czech Republic & 260404 & 257821 & 258780 & 264811 & 280704 & 285464 \\
\hline \multicolumn{7}{|c|}{ NUTS 3} \\
\hline Prague & 3431.31 & 3625.72 & 3862.73 & 4273.64 & 5353.17 & 7496.98 \\
\hline Central Bohemia Region & 34809.22 & 34093.89 & 34223.96 & 35457.25 & 37302.34 & 35853.44 \\
\hline South Bohemia Region & 29264.47 & 29018.78 & 28933.95 & 29510.96 & 30953.58 & 30005.19 \\
\hline The Plzen Region & 21974.59 & 21837.48 & 21774.01 & 21947.11 & 23103.28 & 23020.30 \\
\hline The Karlovy Vary Region & 4341.42 & 4557.69 & 4690.88 & 4810.01 & 5231.64 & 7197.71 \\
\hline The Usti Region & 11169.48 & 10888.41 & 11185.08 & 11890.72 & 12789.42 & 14051.18 \\
\hline The Liberec Region & 5673.12 & 5506.05 & 5657.03 & 5945.62 & 6448.10 & 8288.99 \\
\hline The Hradec Kralove Region & 20066.07 & 19633.43 & 19838.38 & 20440.19 & 21959.11 & 22189.16 \\
\hline The Pardubice Region & 20340.10 & 20207.39 & 20368.80 & 20418.75 & 21592.56 & 21739.44 \\
\hline The Vysocina Region & 29322.75 & 29556.64 & 29382.51 & 30093.57 & 31951.93 & 30993.66 \\
\hline The South Moravian Region & 27505.51 & 27328.47 & 27497.00 & 28408.36 & 30635.12 & 30005.95 \\
\hline The Olomouc Region & 20313.38 & 20273.54 & 20152.22 & 20107.39 & 20820.25 & 20880.97 \\
\hline The Zlin Region & 14426.18 & 14088.22 & 14077.79 & 14067.96 & 14471.62 & 15253.08 \\
\hline The Moravian-Silesian Region & 17766.39 & 17205.28 & 17135.65 & 17439.47 & 18091.87 & 18487.95 \\
\hline
\end{tabular}

Source:Data on the Czech Republic are from the Czech Statistical Office (2015b), the regional data are own calculation Table 3: Regional net capital stock in the Czech Republic, NACE A, constant prices of 2010, millions CZK. 


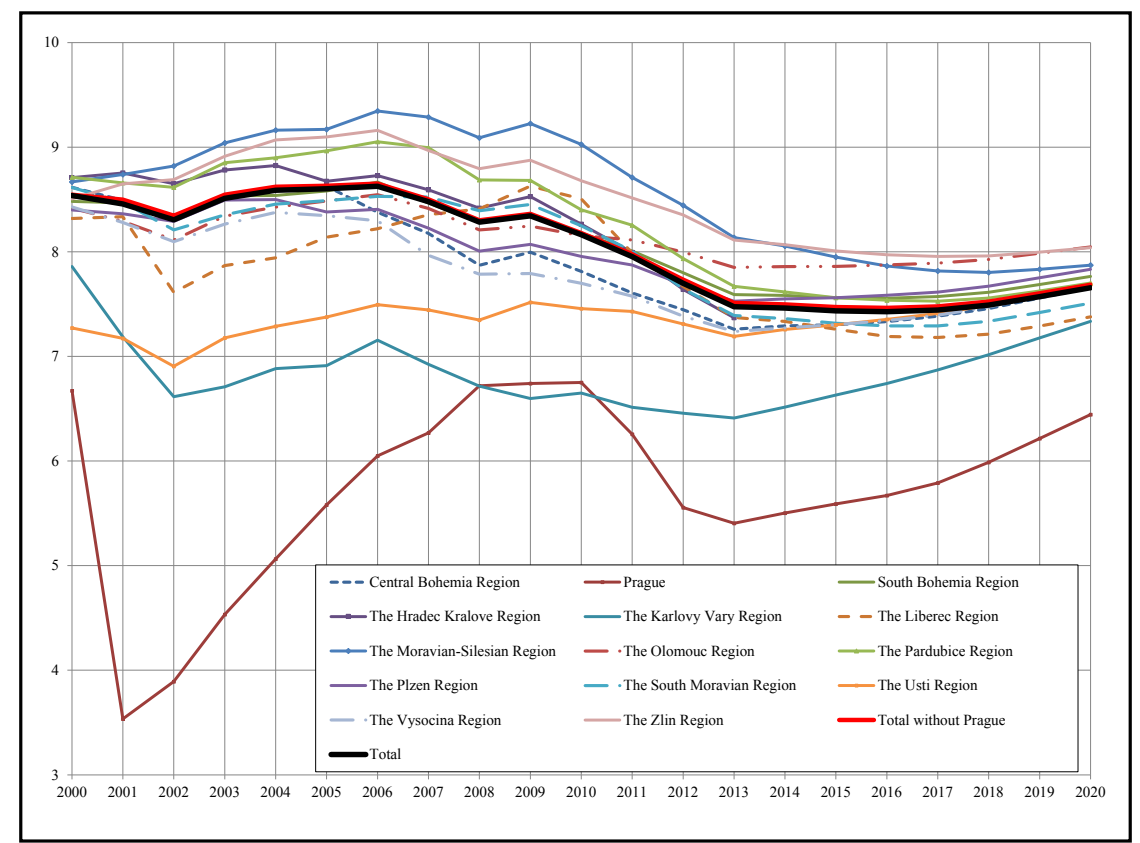

Source: own calculation

Figure 2: Age of machinery and equipment in NACE A in Czech regions (own calculation).

This region recorded a similar share on total gross fixed capital as Prague (1.59\% in 2013). The third region with the lowest age of machinery - the Usti region - coincides with the region with the fourth lowest share on total gross fixed capital $(4.14 \%$ in 2013). On the other hand, the highest age occurs in the Moravian-Silesian Region (8.13 years in 2013), which shows that the relation between the share and age cannot be generalised as the region does not belong among the regions with the highest share of capital stock (5.93\% of total machinery and equipment in 2012 represents the sixth lowest value).

The most significant regions with an individual share higher than $10 \%$ are the South and Central Bohemia regions, the Vysocina region and the South Moravian region, reaching a total share of $48.75 \%$ of gross fixed capital by the end of the examined period. The average age of machinery in the regions reaches 8.22 years, which stays slightly under the average of the whole country. The average max-min difference equals 0.38 years.

The Vysocina and Central Bohemia regions record the highest numbers of cattle and Vysocina has also the highest pig livestock (CZSO, 2015a). These two regions are also the regions with the lowest average age of machinery and equipment if we omit the three above mentioned regions with a small share of capital. On the other hand, the Plzen (a region with the third highest cattle stock) and Pardubice (the third highest pig livestock) regions represent the areas which are above the average age. However, a deeper examination of the link between the type of the predominant production and the age development will be the aim of our future research.

The data show the convergence of the average age of machinery and equipment across the regions. This arises due to a faster increase of investment in the regions with a higher average age in comparison with the regions with a lower age of machinery and equipment.

Figure 3 and 4 show the average age of capital in individual regions. For all regions the average age of Transport equipment remains lower than the average age of the stationary structure so regions must realize an annual growth of investment to keep the average age on the current level. Prague - where the average age is the lowest - should correspondingly record the highest annual growth. To keep the average age at 5.4 years (2013) the annual growth should reach $13 \%$. The second region - Karlovy Vary - should keep a $9 \%$ annual growth. The Moravian-Silesian and Zlin regions find themselves in a reversed position, with an almost similar necessary annual growth of approximately 4\%. For comparison, in the period of 2005-2013 the average annual growth of gross fixed capital formation in constant prices reached $1.64 \%$ for the whole Czech economy, but $8.30 \%$ in NACE A (the Czech Statistical Office, 2015b). 


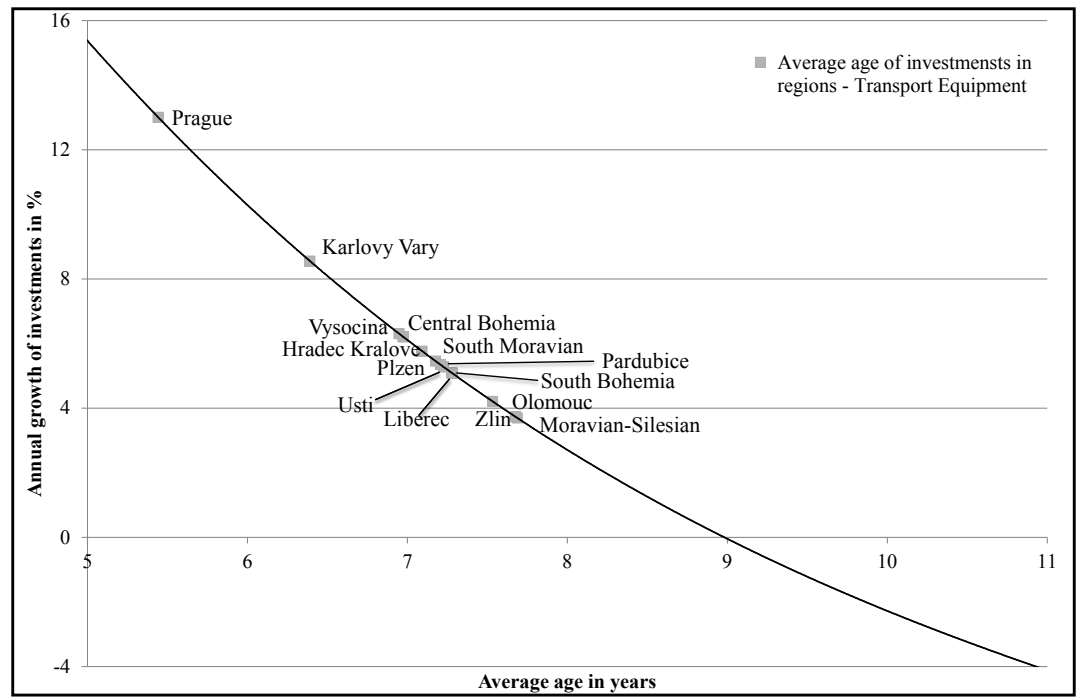

Source: own calculation

Figure 3: Average age of Transport equipment in 2013 in NACE A in Czech regions and relationship with necessary annual growth of investment to keep this average age constant (stable structure).

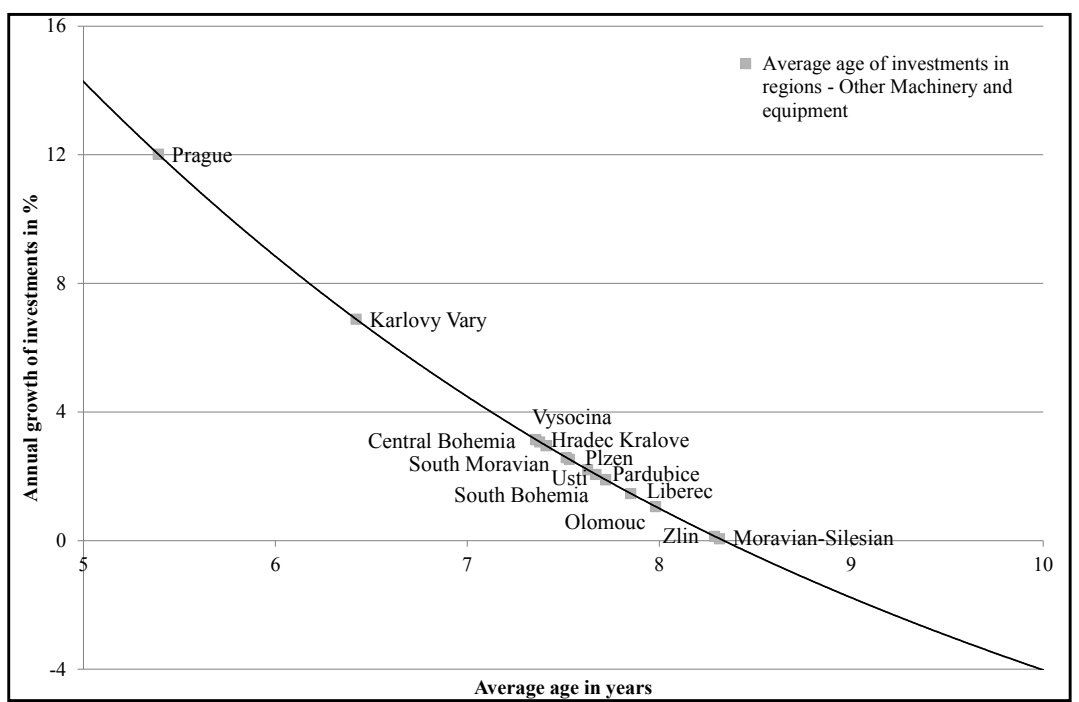

Source: own calculation

Figure 4: Average age of Other machinery and equipment in 2013 in NACE A in Czech regions and relationship with necessary annual growth of investment to keep this average age constant (stable structure).

For Other machinery and equipment, the situation differs slightly. The first two regions remain the same as for Transport equipment - Prague and The Karlovy Vary region. Prague with the average age of capital of 5.4 years should keep an annual growth of new investment at $12 \%$; otherwise the average age is going to increase. The Karlovy Vary region should maintain an annual growth of new investment at 7\%. Regions with the highest average age in 2013 - The Moravian-Silesian and Zlin regions - have reached the age level of stationary structure and to preserve their average age of capital the amount of new investment does not need to change. If those regions realised an annual growth of new investment the average age would decrease.

The age of machinery reaches a below the stationary level and was decreasing in the examined period. Such development must be connected with the growth of capital stock. The described behaviour may be observed in a developing industry. However, Czech agriculture is also 
characterised by a decrease in labour force (CZSO, 2015a). Therefore, the investment behaviour and the age development also emerges from the factor substitution.

Agriculture relates strongly with land which represents a production factor of a nearly constant (or slightly decreasing) quantity. Thus the reduction of labour force must reach its limits and at the same time the necessity of growing capital stock is likely to diminish. Since even a constant age below the stationary age requires an exponential growth of investment in constant prices, a fully developed industry with growth limits will reach a state fluctuating around the stationary structure and age. In international comparison (Krejčí et al., 2015), the age of fixed capital in United States of America and Commonwealth of Australia show a significantly smoother progression. Such development could be assumed in a developed industry.

Carrying out an age analysis shows that modernisation goals are partly fulfilled - the average age in the examined period is decreasing. Nevertheless, a proper evaluation is impossible as the desired age wasn't specified in the strategy documents. Moreover, the indicator should also work as a justification of the goal. The real necessityof modernisation in the whole industry is justifiable and long term sustainable only in case when the age is above the stationary level. Therefore, as the regional average age is below the stationary level the modernisation goal is currently justifiable only for strictly specified groups or smaller areas at the level of disaggregation that is impossible to cover by data of national accounts statistics.

Table 4 shows structure variability according to (7) and (8). The results show that the highest difference between a real structure and a stationary and stable structure for all categories except one is in Prague. Zlin and Olomouc regions recorded their age structures very close to the stationary structure and if we compare the real and stable structure, the Plzen region is closing on it. The heading of the columns of "big" and "small" are connected with another disaggregation. The category "small" represents the institutional sector of Households (legal form of natural person holders). The "big" category contains all other institutional sectors, mainly non-financial institutions (legal forms vary - limited liability companies, joint stock companies and cooperatives). From that point of view, the closest to the stationary or stable structure is the category of Other machinery and equipment in the "big" subcategory.

Differences among age structures are graphically expressed in figure 5 and 6 . Values for Zlin and Olomouc regions represent age structures with the closest structure to the stable structure and both examples of Prague show a high variability

\begin{tabular}{|c|c|c|c|c|c|c|c|c|}
\hline \multirow{3}{*}{ Region } & \multicolumn{4}{|c|}{$D^{s}$} & \multicolumn{4}{|c|}{$D^{b}$} \\
\hline & \multicolumn{2}{|c|}{$\begin{array}{c}\text { Transport } \\
\text { Equipment }\end{array}$} & \multicolumn{2}{|c|}{$\begin{array}{c}\text { Other Machinery } \\
\text { and Equipment }\end{array}$} & \multicolumn{2}{|c|}{$\begin{array}{l}\text { Transport } \\
\text { Equipment }\end{array}$} & \multicolumn{2}{|c|}{$\begin{array}{c}\text { Other Machinery } \\
\text { and Equipment }\end{array}$} \\
\hline & small & big & small & big & small & big & small & big \\
\hline Central Bohemia Region & 0.021 & 0.020 & 0.014 & 0.006 & 0.014 & 0.016 & 0.015 & 0.003 \\
\hline Prague & 0.105 & 0.060 & 0.060 & 0.046 & 0.081 & 0.036 & 0.038 & 0.026 \\
\hline South Bohemia Region & 0.019 & 0.019 & 0.012 & 0.004 & 0.014 & 0.016 & 0.013 & 0.002 \\
\hline The Hradec Kralove Region & 0.026 & 0.021 & 0.015 & 0.006 & 0.017 & 0.016 & 0.016 & 0.003 \\
\hline The Karlovy Vary Region & 0.029 & 0.026 & 0.020 & 0.009 & 0.016 & 0.019 & 0.014 & 0.004 \\
\hline The Liberec Region & 0.029 & 0.043 & 0.026 & 0.011 & 0.021 & 0.041 & 0.026 & 0.008 \\
\hline The Moravian-Silesian Region & 0.018 & 0.016 & 0.015 & 0.005 & 0.015 & 0.014 & 0.017 & 0.004 \\
\hline The Olomouc Region & 0.015 & 0.019 & 0.009 & 0.003 & 0.012 & 0.017 & 0.010 & 0.002 \\
\hline The Pardubice Region & 0.022 & 0.020 & 0.011 & 0.004 & 0.016 & 0.016 & 0.013 & 0.003 \\
\hline The Plzen Region & 0.018 & 0.016 & 0.009 & 0.004 & 0.013 & 0.013 & 0.011 & 0.002 \\
\hline The South Moravian Region & 0.026 & 0.024 & 0.014 & 0.005 & 0.019 & 0.020 & 0.015 & 0.003 \\
\hline The Usti Region & 0.033 & 0.036 & 0.027 & 0.012 & 0.024 & 0.032 & 0.029 & 0.009 \\
\hline The Vysocina Region & 0.021 & 0.018 & 0.012 & 0.005 & 0.014 & 0.014 & 0.012 & 0.002 \\
\hline The Zlin Region & 0.014 & 0.015 & 0.011 & 0.003 & 0.011 & 0.013 & 0.013 & 0.002 \\
\hline Total & 0.021 & 0.020 & 0.013 & 0.004 & 0.015 & 0.016 & 0.014 & 0.002 \\
\hline
\end{tabular}

Source:Data on the Czech Republic are from the Czech Statistical Office (2015b), the regional data are own calculation Table 4: Comparison of real age structure of regions in 2013 with stationary and stable structure. 


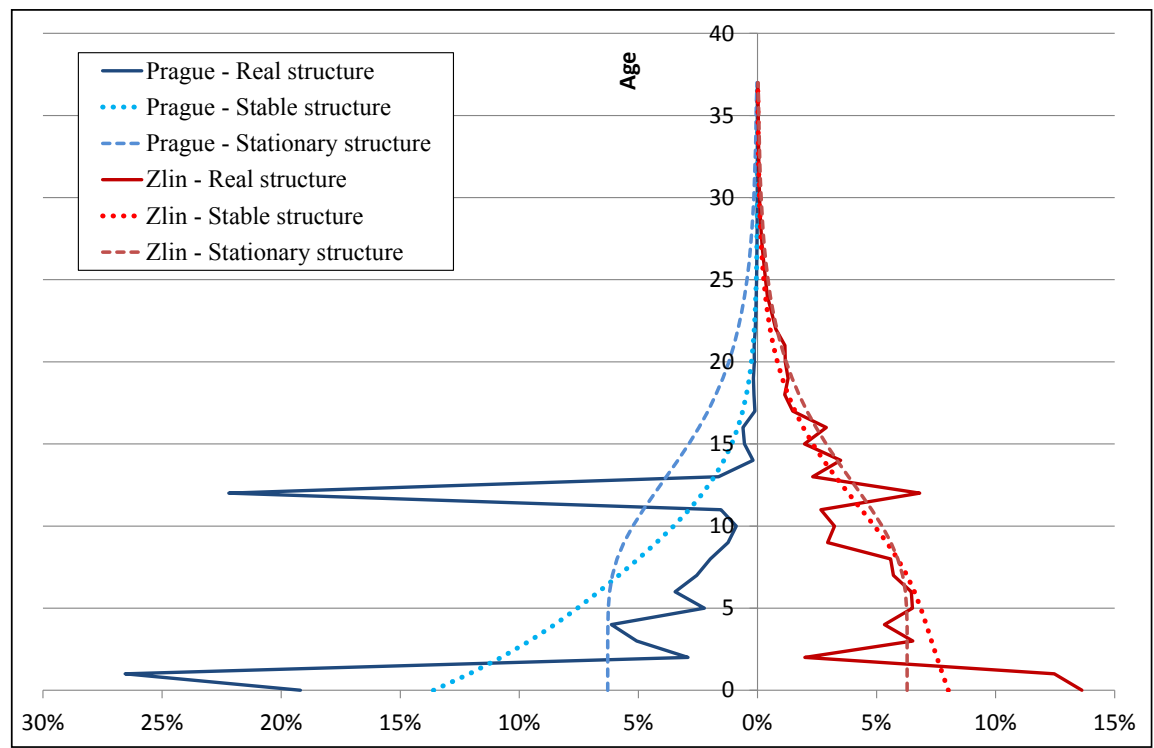

Source: own calculation

Figure 5: Age structure of Transport Equipment-small in Prague and Zlin region (2013), comparison with stationary and stable structure for both regions.

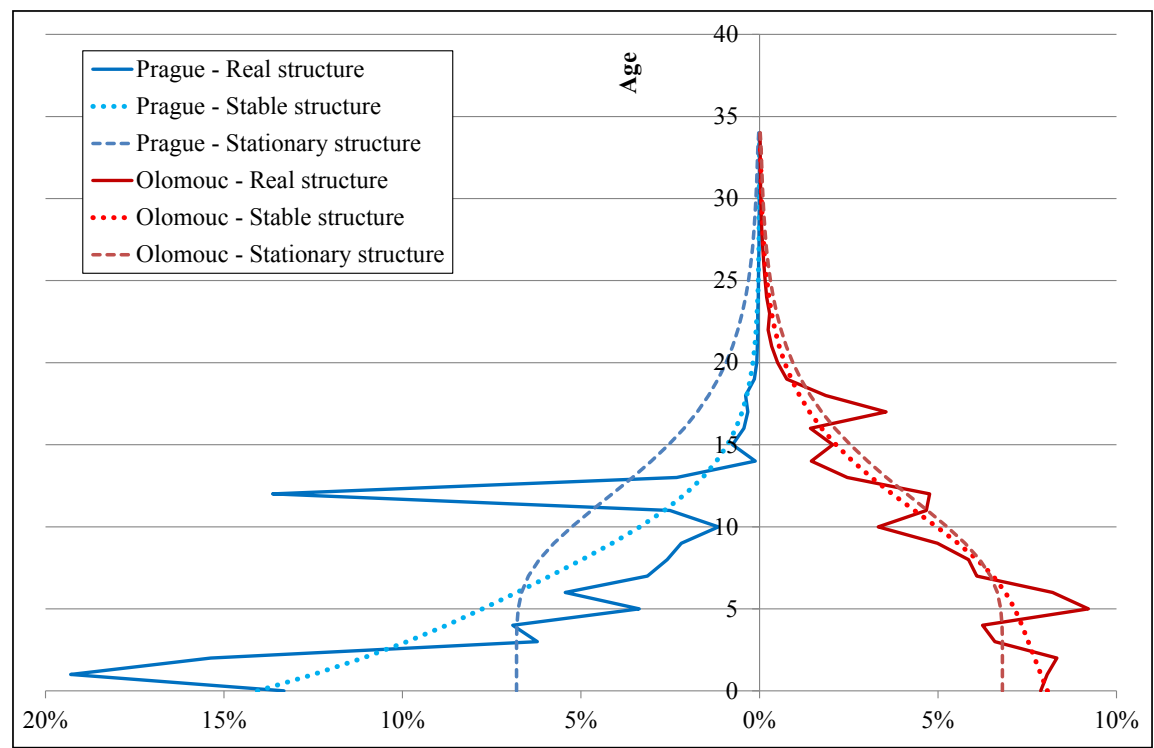

Source: own calculation

Figure 6: Age structure of Other Machinery and equipment-big in Prague and Olomouc region (2013), comparison with stationary and stable structure for both regions.

in structure and a big difference from the stable structure. This arises from an occasionally high amount of new investment in certain years.

\section{Conclusion}

The paper deals with an estimation of the regional age of machinery and equipment in Czech agriculture. To carry this out, we adopt the variant of Perpetual Inventory Method that lead to the age structure. Secondary, we provide regional net fixed capital stock in NACE A for the period of 20082013. If a reader is interested in the differentiation of capital stock according to the type of an asset, we can provide such tables on request.

Similarly to demography, an occasional growth of investment represents a burden for the future. A short-run benefit in the form of a big amount of new assets and a drop of the average age is compensated in the long-run when the surviving part of the old investment pulls the average age up. 
Keeping the age of machinery below the age of a stationary structure requires a permanent increase of investment. Such process could be expected in developing industries (similarly to demography where the same behaviour is observed in developing countries). The developing does not necessarily mean a completely new kind of production but also the establishment of the common economic activity in new region.

Because the size of agriculture as an industry is strongly interconnected with a relatively stable area of land, a permanent growth of investment in constant prices can hardly be expected. The long-term behaviour of developed regional agriculture should be characterised by mild oscillations in investment. Thus the real age equals to the stationary age or fluctuates around the stationary age. Currently, the most heterogeneous (i.e. bearing the aging burden) age structure of machinery and equipment occurs in Prague and the Karlovy Vary region.

From the perspective of modernisation goals as a common part of strategies and plans. Nevertheless, the decreasing average age does not represent the only possible kind of modernisation. A stable age in a developed industry means using

Corresponding author:

Ing. Igor Krejči, Ph.D.

Department of Systems Engineering, Faculty of Economics and Management

Czech University of Life Sciences Prague, Kamýcká 129, Prague 6, 165 21, Czech Republic

Phone:+420 22438 2237,Email: krejcii@pef.czu.cz

\section{References}

[1] Albala-Bertrand and J. M., Feng, H. (2007) "Net Capital Stock and Capital Productivity for China and Regions 1960-2005, An Opitimal Consistency Method", Queen Mary, University of London, 2007, Working paper No. 610, 17 p., ISSN 1473-0278.

[2] Barkaszi L., Keszthelyi S., Csatári E.K. and Pesti C. (2009) "FADN Accountancy Framework and Cost Definitions", FACEPA. [Online]. Available: http://facepa.slu.se/documents/Deliverable_ D1-1-1_LEI.pdf [Accessed 10 May 2016]

[3] Bielik, P. and Hupková, D. (2011) "The technical efficiency analysis-Case of agricultural basic industry in Slovakia", Agris On-line Papers in Economics and Informatics, Vol. 3, No. 1, pp. 3-12, ISSN 1804-1930.

[4] Cohen, A. J., Harcourt and G. C. (2003) "Retrospectives - Whatever happened to the Cambridge capital theory controversies?", Journal of Economic Perspectives, Vol. 17, No. 1, pp. 199-214. ISSN 0895-3309. DOI: 10.1257/089533003321165010.

[5] Czech Statistical Office (2002) "Gross National Income Inventory". Czech Statistical Office. [Online]. Available: https://apl.czso.cz/nufile/CZ_GNI_Rev 2.2.pdf [Accessed 2 Nov. 2015].

[6] Czech Statistical Office (2015a) "Regional accounts", Czech Statistical Office. [Online]. Available: http://apl.czso.cz/pll/rocenka/rocenka.indexnu_reg?mylang=EN [Accessed 13 Oct. 2015].

[7] Czech Statistical Office (2015b) "Annual National Accounts". Czech Statistical Office. [Online]. Available: http://apl.czso.cz/pll/rocenka/rocenka.indexnu_en [Accessed 13 Oct. 2015]. 
[8] Czech Statistical Office (2015c) "Classifications", Czech Statistical Office. [Online]. Available: https://www.czso.cz/csu/czso/classifications [Accessed 2 Nov. 2015].

[9] Čechura, L. (2010) "Estimation of technical efficiency in Czech agriculture with respect to firm heterogeneity", Agricultural Economics, Vol. 56, No. 4, pp. 183-191. ISSN 0139-570X.

[10] Čechura, L. (2012) "Technical efficiency and total factor productivity in Czech agriculture", Agricultural Economics, Vol. 58, No. 4, pp. 147-156. ISSN 0139-570X.

[11] Derbyshire, J., Gardiner, B. and Waights, S. (2013) "Estimating the capital stock for the NUTS2 regions of the EU27", Applied Economics, Vol. 45, No. 9, pp. 1133-1149. ISSN 0003-6846. DOI:10.1080/00036846.2011.613797.

[12] Diewert, W. E. (2005) "Issues in the measurement of capital services, depreciation, asset price changes, and interest rates", In Corrado, C., Haltiwanger J., Sichel D. (eds.) Studies in income and wealth.University Chicago Press, Vancouver, 2005. ISBN 0-226-11612-3.

[13] Doran, G. T. (1981) "There's a S.M.A.R.T. way to write managements's goals and objectives", Management Review, Vol. 70, No. 11, pp. 35-36. ISSN 0025-1895.

[14] European Commision (2005) "IDABC pan-European eGovernment Services", European Commision. [Online]. Available: http://ec.europa.eu/idabc/en/document/2083/5926.html [Accessed 7 Oct. 2015].

[15] European Commision (2010) "Agriculture - FADN: F. A. D. N. DEFINITION OF VARIABLES", European Commision. [Online]. Available: http://ec.europa.eu/agriculture/rica/definitions_en.cfm [Accessed 13 May 2016].

[16] European Commision (2015) "EU Farm Economics Overview based on 2012 FADN data", European Commision. [Online]. Available: http://ec.europa.eu/agriculture/rica/pdf/EU_FEO_FADN_2012. pdf [Accessed 9 May 2016].

[17] European commision (2016) "Final Report Summary - FACEPA (Farm Accountancy Cost Estimation and Policy Analysis of European Agriculture)". [Online]. Available: http://cordis.europa.eu/result/ rcn/143012_en.html [Accessed 12 May 2016].

[18] Harper, P. (2008) "An integrated system of capital flow and stock statistics. Measuring Capital - Beyond the Traditional Measures", In: Proceedings of the Seminar Session of the 2007 Conference of European Statisticians. United Nations Economic Commission For Europe, Geneva, p. 41-48.

[19] Harrod, R. F. and Sraffa, P. (1961) "Production of commodities by means of commodities: Prelude to a critique of economic theory", The Economic Journal, Vol. 71, No. 284, p. 783-787. ISSN 0013-0133. DOI: 10.2307/2228250.

[20] Hlaváček, M., Doucha, T., Fialka, J., Bečvářová, V., Čechura, L., Eck, V., Sekáč, P., Špalková, J.B., Jílek and P., Kreutzer, T. (2012) "Strategie pro růst - české zemědělství a potravinářství v rámci Společné zemědělské politiky EU po roce 2013". [Online]. Available: http://eagri. $\mathrm{cz} / \mathrm{public} / \mathrm{web} / \mathrm{mze} / \mathrm{ministerstvo-zemedelstvi/koncepce-a-strategie/strategie-pro-rust.html}$ [Accessed 21 Oct. 2015].

[21] Hulten, C. R. and Wykoff, F. C. (1996) "'Issues in the measurement of economic depreciation. Introductory remarks", Economic inquiry, Vol. 34, No. 1, p. 10-23. ISSN 0095-2583.

[22] Jarolímek, J., Vaněk, J., Ježek, M., Masner, J. and Stočes, M. (2014) "The telemetric tracking of wild boar as a tool for field crops damage limitation", Plant, Soil and Environment, Vol. 60, No. 9, p. 418-425. ISSN 1214-1178.

[23] Kočišová, K. (2015) "Application of the DEA on the measurement of efficiency in the EU countries", Agricultural Economics, Vol. 61, No. 2, p. 51-62. ISSN 0139-570X. DOI: 10.17221/107/2014-AGRICECON.

[24] Krejčí, I. (2010) "Computation of the Stocks and Consumption of Fixed Capital with use of Markov Chain", In: Proceedings of the 28th International Conference on Mathematical methods in Economics. University of South Bohemia, České Budějovice, pp. 365-370. ISBN 9778-80-7394-218-2. 
[25] Krejčí, I., Mazouch, P., Vltavská, K. and Kvasnička, R. (2015) "Age of machinery and equipment in the Czech agriculture", Agricultural Economics, Vol. 61, No. 8, pp. 356-366. ISSN 0139-570X.

[26] Krejčí, I. and Sixta, J. (2012) "Využití alternativních metod při odhadech stavů a spotřeby fixního kapitálu", Politická Ekonomie, Vol. 60, No. 6, pp. 780-800. ISSN 0032-3233. DOI: $10.18267 /$ j.polek.877.

[27] Latruffe, L. and Piet, L. (2014) "Does land fragmentation affect farm performance? A case study from Brittany, France". Agricultural systems, Vol. 129, p. 68-80. ISSN 0308-521X.

[28] Lawler, J. and Bilson, A. (2013) "Social Work Management and Leadership : Managing Complexity with Creativity", Routledge, New York, NY. 2013. ISBN 1135247056.

[29] Little, J. D. C. (1961) "A Proof for the Queuing Formula: L = $\lambda$ W", Operations Research, Vol. 9, No. 3, pp. 383-387. ISSN 0030-364X.

[30] Lotka, A. J. (1939) "Théorie analytique des associations biologique". Hermann, Paris.

[31] Ministry of Agriculture of the Czech Republic (2008) "Rural Development Programme of the Czech Republic for 2007 - 2013", Ministry of Agriculture of the Czech Republic. [Online]. Available: http://eagri.cz/public/web/file/10574/RDP_November_2008.pdf [Accessed 3 Nov. 2014].

[32] Nowak, A., Kijek, T. and Domańska, K. (2015) "Technical efficiency and its determinants in the European Union agriculture", Agricultural Economics, Vol. 61, No. 6, pp. 275-283. ISSN 0139-570X. DOI: 10.17221/200/2014-AGRICECON.

[33] OECD (2009) "Measuring Capital - OECD Manual 2009". OECD Publishing, Paris. ISBN 978-92-64-02563-9.

[34] Pigou, A. C. (1935) "Net Income and Capital Depletion", Economic Journal, Vol. 45, No. 178, pp. 235-241. ISSN 0013-0133. DOI: 10.2307/2224616.

[35] Robinson, J. (1953) "The Production function and the Theory of Capital", Review of Economic Studies, Vol. 21, No. 2, pp. 81-106. ISSN 1467-937X.

[36] Roubíček, V. (1997) "Úvod do demografie", CODEX Bohemia, Pague. ISBN 80-85963-43-4.

[37] Špička, J. (2014) "The regional efficiency of mixed crop and livestock type of farming and its determinants", Agris On-line Papers in Economics and Informatics, Vol. 6, No. 1, pp. 99-109. ISSN 1804-1930.

[38] Špička, J. and Smutka, L. (2014) "The technical efficiency of specialised milk farms: a regional view", Scientific World Journal, p. 1-13. ISSN. 1537-744X. DOI: 10.1155/2014/985149.

[39] Tijms, H. C. (2003) "A first course in stochastic models", Wiley, Chichester, England. ISBN 0-471-49881-5.

[40] U.S. Bureau of Economic Analysis (2013) "How does BEA estimate the average age of net stocks of fixed assets and consumer durables?", U.S. Bureau of Economic Analysis. [Online]. Available: http://www.bea.gov/faq/index.cfm?faq_id=1031 [Accessed 26 Jan. 2015].

[41] United Nations, European Commission, International Monetary Fund, Organisation for Economic Co-operation and Development, World Bank (2009) "System of national accounts 2008", United Nations, New York. 2009. ISBN 978-92-1-161522-7.

[42] van der Duyn Schouten, F. A. and Vanneste, S. G. (1990) "Analysis and computation of (n, N)strategies for maintenance of a two-component system", European Journal of Operational Research, Vol. 48, No. 2, pp. 260-274, ISSN 0377-2217. DOI:10.1016/0377-2217(90)90379-P.

[43] Vaněk, J., Červenková, E., Jarolímek, J. and Šimek, P.(2010) "State and evaluation of information and communication technologies development in agricultural enterprises in Czech Republic", Plant, Soil and Environment, Vol. 56, No. 3, pp. 143-147. ISSN 1214-1178. 